\title{
Postprandial phase time influences the uptake of TAG from postprandial TAG-rich lipoproteins by THP-1 macrophages
}

\author{
Rosana Cabello-Moruno ${ }^{1}$, Laura Sinausia ${ }^{1}$, Kathleen M. Botham ${ }^{2}$, Emilio Montero ${ }^{3}$, Michael Avella ${ }^{2}$ and \\ Javier S. Perona ${ }^{1 *}$ \\ ${ }^{1}$ Nutrition and Lipid Metabolism, Instituto de la Grasa (CSIC), Avenida Padre García Tejero, 4, 41012 Seville, Spain \\ ${ }^{2}$ Department of Comparative Biomedical Sciences, The Royal Veterinary College, Royal College Street, London NW1 OTU, UK \\ ${ }^{3}$ Emergencies Services, General Hospital, HHUU Virgen del Rocío, Avenida Manuel Siurot s/n, 41013 Seville, Spain
}

(Submitted 27 January 2014 - Final revision received 21 March 2014 - Accepted 16 July 2014 - First published online 23 September 2014)

\section{Abstract}

Postprandial TAG-rich lipoproteins (TRL) can be taken up by macrophages, leading to the formation of foam cells, probably via receptormediated pathways. The present study was conducted to investigate whether the postprandial time point at which TRL are collected modulates this process. A meal containing refined olive oil was given to nine healthy young men and TRL were isolated from their serum at 2, 4 and $6 \mathrm{~h}$ postprandially. The lipid class and apoB compositions of TRL were determined by HPLC and SDS-PAGE, respectively. The accumulation of lipids in macrophages was determined after the incubation of THP-1 macrophages with TRL. The gene expression of candidate receptors was measured by real-time PCR. The highest concentrations of TAG, apoB 48 and apoB100 in TRL were observed at $2 \mathrm{~h}$ after the consumption of the test meal. However, excessive intracellular TAG accumulation in THP-1 macrophages was observed in response to incubation with TRL isolated at $4 \mathrm{~h}$, when their particle size (estimated as the TAG:apoB ratio) was intermediate. The abundance of mRNA transcripts in macrophages in response to incubation with TRL was down-regulated for LDL receptor ( $L D L R$ ), slightly up-regulated for VLDL receptor and remained unaltered for LDLR-related protein, but no effect of the postprandial time point was observed. In contrast, the mRNA expression of scavenger receptors SRB1, SRA2 and CD36 was higher when cells were incubated with TRL isolated at $4 \mathrm{~h}$ after the consumption of the test meal. In conclusion, TRL led to excessive intracellular TAG accumulation in THP-1 macrophages, which was greater when cells were incubated with intermediate-sized postprandial TRL isolated at $4 \mathrm{~h}$ and was associated with a significant increase in the mRNA expression of scavenger receptors.

Key words: TAG-rich lipoproteins: Macrophages: Lipids: Receptors

TAG-rich lipoproteins (TRL) represent a very heterogeneous group of particles consisting of chylomicrons (CM), VLDL and their remnants. CM are assembled in the intestine and mainly contain lipids derived from the diet together with a single molecule of apoB48, while VLDL are generated in the liver and require the presence of apoB100. Once released in the bloodstream, these two types of particles compete for the process of TAG depletion by lipoprotein lipase ${ }^{(1)}$ and for the hepatic pathway of particle clearance mediated by receptors that recognise apoE, mainly LDL receptor (LDLR) and LDLR-related protein $(\mathrm{LRP})^{(2)}$. Therefore, plasma concentrations of TRL are determined by the rates of secretion from the intestine and liver as well as by the rates of catabolism of CM and VLDL ${ }^{(3)}$.

The transport and metabolism of TRL, especially during the postprandial period, have been reported to be associated with atherosclerosis $^{(4,5)}$. TRL and their remnants can penetrate the arterial wall, where they remain trapped and are taken up by macrophages, causing lipid accumulation, which leads to the formation of foam cells and eventually to the formation of the fatty streak, the first visible lesion in atherogenesis. In previous studies, CM remnants have been shown to induce the formation of foam cells in a variety of macrophage populations, including those derived from the human monocyte cell line THP-1 ${ }^{(6-8)}$. The accumulation of cholesterol and TAG in these cells is influenced by the fatty acid composition of the remnants, which modulates their atherogenicity, regardless of their oxidative state ${ }^{(7)}$.

In addition to the macrophage-secreted lipoprotein lipase hydrolysis of TRL and the uptake of the released fatty acids, lipids are believed to enter macrophages by the uptake of whole particles via receptor-mediated pathways ${ }^{(9)}$. Candidates involved in these pathways include LDLR and LRP, as well as

Abbreviations: CE, cholesteryl esters; CM, chylomicrons; FC, free cholesterol; LDLR, LDL receptor; LRP, LDL receptor-related protein; TRL, TAG-rich lipoproteins; VLDLR, VLDL receptor.

*Corresponding author: J. S. Perona, fax +34 954616790, email perona@ig.csic.es 
VLDL receptor (VLDLR) and non-apoE-dependent receptors, such as the scavenger receptors A2 (SRA2), B1 (SRB1) and $\mathrm{CD} 36$, the major members of the scavenger receptor family expressed in macrophages ${ }^{(10-12)}$. Direct phagocytosis has also been proposed as a mechanism for the uptake of TRL by macrophages, although it is thought to play only a minor role ${ }^{(13)}$. Evidence from previous experiments with THP-1 macrophages suggests that $\mathrm{CM}$ remnants are mainly taken up by LRP and $\operatorname{LDLR}^{(14)}$. However, the exact mechanisms by which TRL cause lipid accumulation in macrophages are not yet completely defined.

The processes by which TRL are taken up by macrophages are likely to influence the amount of lipids accumulated intracellularly. It is well known that the lipid composition of postprandial TRL affects their particle size and also influences the mechanisms related to their internalisation and intracellular accumulation ${ }^{(15-17)}$. Previously, it was thought that larger lipoproteins cannot penetrate the arterial intima and are, therefore, not available for uptake by macrophages in the subendothelial space ${ }^{(18)}$, but now there is evidence indicating that CM-sized particles can be taken up by macrophages ${ }^{(19)}$. However, these studies have also shown that the mechanisms responsible for internalisation are affected by the TAG composition of the particles, which, in turn, affects their size.

Earlier studies have established that TRL particles isolated at different time points during the postprandial period differ in their size and lipid composition ${ }^{(20)}$ and thus may be taken up differentially by macrophages. In the present study, we investigated the effects of TRL obtained from healthy subjects at 2, 4 and $6 \mathrm{~h}$ postprandially after a fat challenge on lipid accumulation and foam cell formation in macrophages derived from the human monocyte cell line THP-1. We also investigated the effect of postprandial TRL isolated at different time points on the gene expression of the apoE-dependent and scavenger receptors believed to be involved in the uptake of particles by these cells.

\section{Experimental methods}

\section{Subjects and study design}

A total of nine healthy men aged $26 \cdot 2$ (SEM $4 \cdot 3$ ) years with a BMI of 23.7 (SEM 2.0$) \mathrm{kg} / \mathrm{m}^{2}$ participated in the study. Subjects were excluded if they suffered from any digestive or metabolic disorder, were taking dietary supplements or were under medication of any kind. A fasting blood sample was collected to ensure that the recruited subjects had plasma TAG and glucose concentrations within normal limits (Table 1). The present study was conducted according to the guidelines laid down in the Declaration of Helsinki of 1975 (revised in 2000), and all procedures involving human subjects were approved by the Institutional Committee on Human Research (Hospital Universitario Virgen del Rocio, Seville, Spain). Written informed consent was obtained from all subjects.

The experiment was carried out for 3 weeks, with the 2nd week being the washout period during which the subjects resumed consuming their normal diet. The subjects were
Table 1. Baseline data of normolipidaemic men who participated in the present study (Mean values with their standard errors, $n 9$ )

\begin{tabular}{lcc}
\hline & Mean & SEM \\
\hline Total cholesterol $(\mathrm{mmol} / \mathrm{l})$ & 3.78 & 0.57 \\
LDL-cholesterol $(\mathrm{mmol} / \mathrm{l})$ & 2.35 & 0.31 \\
HDL-cholesterol (mmol/l) & 1.60 & 0.47 \\
TAG (mmol/l) & 0.68 & 0.19 \\
ApoA (g/l) & 1.49 & 0.23 \\
ApoB (g/l) & 0.55 & 0.07 \\
LDL:HDL & 1.60 & 0.4 \\
ApoB:ApoA & 0.40 & 0.1 \\
\hline
\end{tabular}

given 1 litre of refined olive oil 1 week before the start of the study to minimise the effect of their habitual dietary oil. On the last day of this week, the subjects consumed a meal that consisted of one slice of brown bread $(28 \mathrm{~g})$, one cup of skimmed yogurt $(125 \mathrm{~g})$ and plain pasta ( $100 \mathrm{~g}$, cooked with $200 \mathrm{ml}$ of water) with tomato sauce $(130 \mathrm{~g})$ previously mixed with refined olive oil $(70 \mathrm{~g})$. The oil provided $2587 \mathrm{~kJ}$ of energy, while the whole meal provided $4523 \mathrm{~kJ}$, distributed as follows: $32.5 \%$ carbohydrate; $7 \cdot 6 \%$ protein; $59.9 \%$ fat. The refined olive oil, with oleic acid (18:1n-9), palmitic acid (16:0), linoleic acid (18:2n-6) and stearic acid (18:0) proportions of 78.7 , $10 \cdot 6,5 \cdot 2$ and $3 \cdot 3 \%$, respectively, was kindly supplied by Oleicola El Tejar, S.A.

The subjects were asked to consume a low-fat dinner the evening before the postprandial study and to abstain from drinking alcohol and smoking for $24 \mathrm{~h}$. On arrival to the laboratory, after an overnight fast (12 h), a cubital vein was catheterised and a baseline blood sample was collected immediately before the consumption of the test meal. After the consumption of the test meal, blood samples were collected hourly for a period of $7 \mathrm{~h}$. During the course of the experiment, the subjects were allowed to drink water and to undertake only light activities.

Serum was recovered by centrifugation $\left(1620 \mathrm{~g}, 30 \mathrm{~min}, 4^{\circ} \mathrm{C}\right)$ and sodium azide, phenylmethylsulfonyl fluoride and aprotinin (Sigma-Aldrich) were added to it at a final concentration of $1 \mathrm{mmol} / 1,10 \mu \mathrm{mol} / \mathrm{l}$ and $0.5 \mathrm{mg} / \mathrm{l}$, respectively.

\section{Isolation of postprandial TAG-rich lipoproteins}

Postprandial TRL were isolated from $4.5 \mathrm{ml}$ of serum collected at 2, 4 and $6 \mathrm{~h}$ after the consumption of the test meal. Serum was layered under $6 \mathrm{ml}$ of $\mathrm{NaCl}$ solution $(d=1.006 \mathrm{~kg} / \mathrm{l})$, and TRL were obtained by a single ultracentrifugation spin $\left(39000 \mathrm{rpm}, 18 \mathrm{~h}, 12^{\circ} \mathrm{C}\right.$ ). Ultracentrifugation was performed using a SW 41Ti swinging-bucket rotor in a Beckman L8-70M preparative ultracentrifuge (Beckman Instruments). Different postprandial time points were chosen for the isolation of TRL according to the hours at which maximum and minimum serum TAG concentrations are found ${ }^{(20)}$. TRL were rapidly frozen at $-80^{\circ} \mathrm{C}$ and thawed just before use. As extreme changes in temperature might cause alterations in TRL structure, particles were checked for aggregations before use in culture. 
(a)

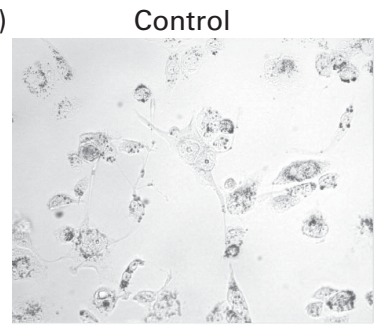

(c)

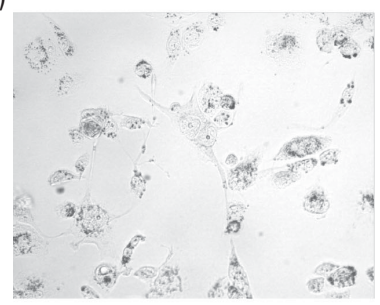

(e)

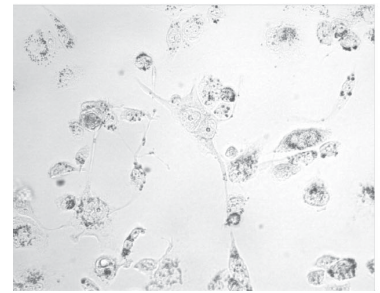

(b)

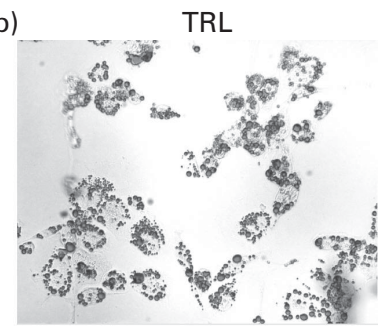

(d)

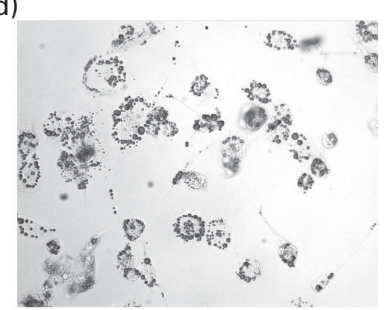

(f)

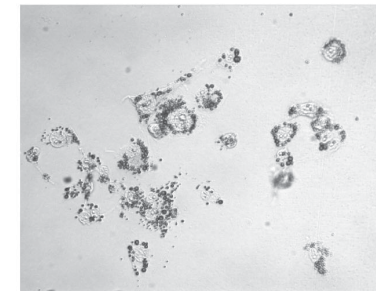

Fig. 1. Microphotographs of THP-1 macrophages incubated for $24 \mathrm{~h}$ in the presence or absence (control) of TAG-rich lipoproteins (TRL, $15 \mu \mathrm{g}$ total cholesterol $/ \mathrm{ml}$ ) isolated at 2, 4 and $6 \mathrm{~h}$ after the consumption of the test meal and stained with Oil Red $\mathrm{O}$ for visualising lipid accumulation. Typical images from nine experiments are shown. (a) $2 \mathrm{~h}$ control, (b) $2 \mathrm{~h}$ TRL, (c) $4 \mathrm{~h}$ control, (d) $4 \mathrm{~h} \mathrm{TRL}$, (e) $6 \mathrm{~h}$ control, and (f) $6 \mathrm{~h}$ TRL.

\section{Determination of TAG-rich lipoprotein lipid class and apoB compositions}

TRL obtained from $4.5 \mathrm{ml}$ of serum (approximately $1 \mathrm{ml}$ ) were adjusted to a final volume of $1.5 \mathrm{ml}$ with $\mathrm{KCl}$ solution $(0 \cdot 1 \mathrm{~m})$. Total lipids in TRL were extracted according to the method of Folch et al. ${ }^{(21)}$ with slight modifications. The extracted lipids were dissolved in $1 \mathrm{ml}$ of chloroform-methanol (2:1, v/v). Aliquots were prepared and kept at $-20^{\circ} \mathrm{C}$ until use.

The lipid class composition of TRL was determined by HPLC as described by Perona \& Ruiz-Gutierrez ${ }^{(22)}$. In brief, $10 \mathrm{ml}$ of lipids were dissolved in chloroform-methanol (2:1, v/v) and injected by an automatic sampler into a 2690 Alliance liquid chromatograph (Waters) controlled by the Empower System (Waters). Detection was accomplished with a model 2420 light-scattering detector (Waters). Lipid classes were separated on a LiChrospher diol column (250, 4.6, $5 \mathrm{~mm}$ particle sizes; Merck) using a gradient-elution system containing hexane, 2-propanol and methanol. Stock solutions of cholesteryl oleate, triolein, cholesterol and phosphatidylcholine were prepared in chloroform-methanol $(2: 1, \mathrm{v} / \mathrm{v})$ and used as standards for the identification and quantification of cholesteryl esters (CE), TAG, free cholesterol (FC) and phospholipids, respectively. The precision of the method ranged from 2.4 to $4.0 \%$ for lipid standards and from 6.8 to $11.7 \%$ for CM obtained $4 \mathrm{~h}$ after the fat challenge .

ApoB48 and apoB100 were quantified after separation by SDS-PAGE (Fig. 2). Electrophoresis was carried out using the buffer system described by Laemmli ${ }^{(23)}$. Gels contained a $4-15 \%$ acrylamide gradient, $0 \cdot 1 \%$ SDS and $0 \cdot 375 \mathrm{~m}$-Tris. The acrylamide gradient was poured using a Hoefer SG-50 two-chamber, gravity-flow gradient maker (Hoefer) A stacking gel (5\% acrylamide, $0 \cdot 1 \%$ SDS, 2 mM-EDTA, and $0.11 \mathrm{~m}$-Tris- $\mathrm{HCl}, \mathrm{pH} 6.8)$ was added with a ten-slot wellforming comb. Non-delipidated lipoprotein samples $(3 \mathrm{mg}$ of protein) were reduced in SDS sample buffer (3\% SDS, 0.8 mm-EDTA, 5\% mercaptoethanol, $0.004 \%$ bromophenol blue, $0.05 \mathrm{M}$-Tris- $\mathrm{HCl}$, and $10 \%$ glycerol, $\mathrm{pH}$ 6.8) for $3 \mathrm{~min}$ at $100^{\circ} \mathrm{C}$. The gels were run at $60 \mathrm{~V}$ for $3 \mathrm{~h}$. The gels were fixed with a 10\% methanol-7\% acetic acid solution for $30 \mathrm{~min}$ and stained overnight with SYPRO Ruby Protein Gel Stain (Molecular Probes). Destaining was achieved by $1 \mathrm{~h}$ wash with the $10 \%$ methanol-7\% acetic acid solution. The two molecular weight forms of apoB were clearly separated in this gel system. Apo were identified by comparing the distance that they migrated in the gels with the distance travelled by known molecular weight standards (SigmaMarker, Wide Range (molecular weight 6.5-250.0 kDa)). The gels were scanned using the Gel Doc 1000 system (Bio-Rad) and analysed using the software Molecular Analyst version 1.6 (Bio-Rad). All samples from the same subject were run on the same gel to enable comparison after separation and staining under the same conditions. Considering that apoB100 and apoB48 exhibit the same chromogenicity ${ }^{(24)}$, the relative amounts of the two isoforms were calculated from the staining intensity, and their absolute masses were calculated from the total apoB mass determined by immunoturbidimetry (Sigma Diagnostics).

\section{Culture of THP-1 macrophages}

THP-1 monocytes $\left(3-9 \times 10^{5}\right.$ cells $\left./ \mathrm{ml}\right)$ grown in Roswell Park Memorial Institute 1640 medium supplemented with fetal bovine serum $(10 \% \mathrm{v} / \mathrm{v})$, penicillin $(60 \mu \mathrm{g} / \mathrm{ml} ; 100 \mathrm{U} / \mathrm{ml})$, streptomycin $(100 \mathrm{mg} / \mathrm{ml})$ and 2-mercaptoethanol $(20 \mu \mathrm{M})$ were induced to differentiate into macrophages by incubation with phorbol 12 -myristate 13 -acetate $(200 \mathrm{ng} / \mathrm{ml})$ for $72 \mathrm{~h}$ at $37^{\circ} \mathrm{C}$ in $5 \% \mathrm{CO}_{2}-95 \%$ air. The confluency of adherent cells was $70-80 \%$ in all cell-culture experiments, and cell viability was $>95 \%$ and was unaffected on incubation with TRL.

\section{Oil Red O staining}

Cells $\left(3 \times 10^{5}\right.$ cells $\left./ \mathrm{ml}\right)$ were incubated with TRL (15 $\mu \mathrm{g}$ cholesterol $/ \mathrm{ml}$ ) for $24 \mathrm{~h}$, washed with PBS and $60 \%$

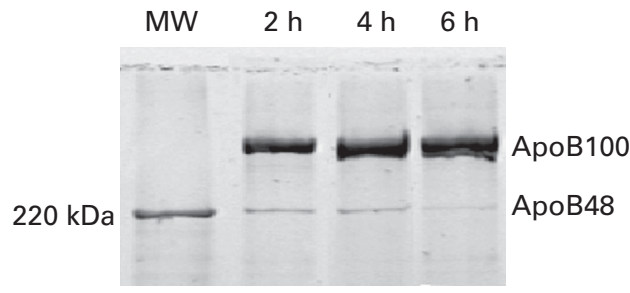

Fig. 2. SDS-PAGE analysis of apoB48 and apoB100 separated from human TAG-rich lipoproteins isolated at 2, 4 and $6 \mathrm{~h}$ after the consumption of the test meal. MW, molecular weight markers. 
propan-2-ol, and then stained with Oil Red O $(0.5 \%(\mathrm{w} / \mathrm{v})$ in $40 \%$ propan-2-ol $\left./ \mathrm{H}_{2} \mathrm{O}(\mathrm{v} / \mathrm{v})\right)$. After $15 \mathrm{~min}$, the stain was removed and cells were washed twice with PBS.

\section{Determination of cell lipid composition}

Cells $\left(8 \times 10^{5}\right.$ cells $\left./ \mathrm{ml}\right)$ were incubated with TRL $(15 \mu \mathrm{g}$ cholesterol $/ \mathrm{ml}$ ) for $48 \mathrm{~h}$ and then washed with PBS and scraped off the plates with $700 \mathrm{ml}$ of PBS. Cells were lysed by sonication for $5 \mathrm{~s}$ (two cycles) at $50 \mathrm{~W}$ using a Bandelin SONOPULS HD2070 apparatus (Bandelin Electronics). An aliquot of $50 \mathrm{ml}$ was used to determine the protein content using the method of Bradford. Lipids were extracted using the method of Folch et al. ${ }^{(21)}$. TAG, FC and CE (total cholesterol - CE) concentrations were determined by enzymatic analysis using commercial enzymatic reagent kits (Alpha Laboratories).

\section{Analysis of mRNA}

THP-1 macrophages $\left(6 \times 10^{6}\right.$ cells $\left./ \mathrm{ml}\right)$ were incubated with TRL $(15 \mu \mathrm{g}$ cholesterol $/ \mathrm{ml})$ for $16 \mathrm{~h}$ and then total RNA was extracted (GenElute Mammalian Total RNA Kit; Sigma-Aldrich) with DNAase I treatment according to the manufacturer's instructions. RT and oligo(deoxythymidine) primers were obtained from Promega and were used for reverse transcription. The mRNA abundances of LDLR, LRP, VLDLR, CD36, SRA2, SRB1 and the housekeeping gene glyceraldehyde 3-phosphate dehydrogenase $(G A P D H)$ were determined by real-time PCR (quantitative PCR) using SYBR Green quantitative fluorescence (SYBR Green JumpStart Taq ReadyMix, Sigma-Aldrich) and an Opticon 2 LightCycler system (MJ Research). The forward and reverse primers and the PCR conditions employed are summarised in Table $\mathrm{S} 1$ (available online). $C_{\mathrm{t}}$ values were determined using the automated threshold analysis (Opticon Monitor 2 software; Bio-Rad). Data were normalised using values obtained for $G A P D H$, and the fold change in mRNA expression in TRL-treated macrophages $v$. control macrophages was determined using the method of $\mathrm{Pfaffl}^{(25)}$.

\section{Statistical analyses}

Results are expressed as means with their standard errors ( $n$ 9), unless otherwise stated. Statistical analyses were conducted using the GraphPad Prism ${ }^{\circledR} 5$ statistical package (GraphPad Software, Inc.). Statistical significance of postprandial changes was analysed using one-way ANOVA followed by Tukey's multiple comparison test. Differences were considered statistically significant at $P<0 \cdot 05$.

\section{Results}

\section{Lipid class and apoB compositions of postprandial TAG-rich lipoproteins}

The lipid class composition of TRL isolated at 2, 4 and $6 \mathrm{~h}$ after the consumption of the test meal is summarised in Table 2. The proportion of TAG in TRL was highest at $2 \mathrm{~h}$ and declined subsequently, becoming significantly lower at $6 \mathrm{~h}$ when compared with that at 2 and $4 \mathrm{~h}$. The reduction of TAG content resulted in a proportional significant increase in CE and phospholipid concentrations at 4 and $6 \mathrm{~h}$. The relative proportions of FC and total cholesterol in TRL remained unaltered throughout the postprandial period. Both apoB48 and apoB100 were quantified in postprandial TRL, and the highest concentrations were observed at $2 \mathrm{~h}$ and the lowest at $4 \mathrm{~h}$. The TAG:apoB100 and TAG:apoB48 ratios were used as estimates of the particle size at different postprandial time points. The highest ratio (largest particles) was found at $2 \mathrm{~h}$ and the lowest ratio (smallest particles) at $6 \mathrm{~h}$, with the latter being significantly different from the ratios at 2 and $4 \mathrm{~h}$.

\section{Intracellular lipid composition in THP-1 macrophages}

Microphotographs of THP-1 macrophages incubated for $24 \mathrm{~h}$ in the absence (control) or presence of TRL isolated at 2, 4 or $6 \mathrm{~h}$ after the consumption of the test meal are shown in Fig. 1. Cells were stained with Oil Red $O$ to visualise the incorporation of lipids into the cytoplasm. Images revealed a light

Table 2. Lipid class composition, apoB content and TAG:apoB ratios of TAG-rich lipoproteins (TRL) obtained from healthy subjects after the consumption of the test meal

(Mean $\ddagger$ values with their standard errors, $n 9$ )

\begin{tabular}{|c|c|c|c|c|c|c|}
\hline & \multicolumn{2}{|c|}{$2 \mathrm{~h}$} & \multicolumn{2}{|c|}{$4 \mathrm{~h}$} & \multicolumn{2}{|c|}{$6 \mathrm{~h}$} \\
\hline & Mean & SEM & Mean & SEM & Mean & SEM \\
\hline TAG (mg/100 mg lipids) & $76 \cdot 2$ & 1.9 & $72 \cdot 4$ & 1.6 & $71 \cdot 2^{*} \dagger$ & $2 \cdot 5$ \\
\hline TC§ (mg/100 mg lipids) & $18 \cdot 2$ & 1.4 & $19 \cdot 1$ & $1 \cdot 1$ & $19 \cdot 3$ & 1.9 \\
\hline CE (mg/100 mg lipids) & $4 \cdot 7$ & 0.3 & $6 \cdot 6^{*}$ & 0.9 & $6 \cdot 9^{*}$ & 0.9 \\
\hline FC (mg/100 mg lipids) & $13 \cdot 5$ & $1 \cdot 1$ & $12 \cdot 5$ & 0.9 & $12 \cdot 5$ & $1 \cdot 1$ \\
\hline PL (mg/100 mg lipids) & $5 \cdot 6$ & 0.6 & $8 \cdot 5^{\star}$ & 0.9 & $9 \cdot 5^{\star}$ & 1.0 \\
\hline ApoB100 ( $\mu \mathrm{g} / \mathrm{mg}$ protein) & 133.5 & $60 \cdot 2$ & $70 \cdot 6^{\star \star}$ & $21 \cdot 0$ & $114 \cdot 6$ & $30 \cdot 5$ \\
\hline ApoB48 ( $\mu \mathrm{g} / \mathrm{mg}$ protein) & $6 \cdot 3$ & $4 \cdot 3$ & 3.4 & $2 \cdot 0$ & 4.4 & $2 \cdot 2$ \\
\hline TAG:apoB100|| & $49 \cdot 8$ & $20 \cdot 6$ & $37 \cdot 6$ & $14 \cdot 3$ & $12 \cdot 1^{* * *} \dagger †$ & $3 \cdot 0$ \\
\hline TAG:apoB48\| & $1514 \cdot 3$ & $1006 \cdot 7$ & 984.5 & $433 \cdot 5$ & $363 \cdot 7^{*}+\dagger$ & $168 \cdot 6$ \\
\hline
\end{tabular}

TC, total cholesterol; CE, cholesteryl esters; FC, free cholesterol; PL, phospholipids.

Mean value was significantly different from that at $2 \mathrm{~h}:{ }^{\star} P<0.05$; ${ }^{\star \star} P<0.01$; ${ }^{\star \star \star} P<0.001$.

Mean value was significantly different from that at $4 \mathrm{~h}: \dagger P<0.05$; $\dagger+P<0.01$.

$\ddagger$ Mean from nine separate experiments each using TRL obtained from different subjects.

$\S T C$ is calculated as the sum of $F C$ and $C E$.

II TAG:apoB ratios were calculated after normalising by $\mathrm{mg}$ of TRL protein. 
staining in control cells and a strong red staining in cells incubated with TRL, confirming the intracellular incorporation of lipids from lipoproteins. There were also some differences related to the postprandial time point, with particles isolated at $6 \mathrm{~h}$ inducing a visually noticeable lower staining intensity compared with those isolated at 2 or $4 \mathrm{~h}$ after the consumption of the test meal.

THP-1 macrophages were also incubated with postprandial TRL to evaluate their influence on intracellular lipid mass (Fig. 3). The incubation of macrophages with TRL induced a statistically significant increase in the intracellular concentrations of TAG compared with control cells (absence of TRL). The strongest effect was observed when macrophages were incubated with TRL isolated at $4 \mathrm{~h}$ after the consumption of the test meal than when incubated with TRL isolated at 2 and $6 \mathrm{~h}$. The contribution of FC and $\mathrm{CE}$ to the accumulation of lipids in cells was statistically indistinguishable from that in control cells at all time points.

\section{Macrophage receptor gene expression}

The effect of TRL isolated at 2, 4 and $6 \mathrm{~h}$ after the consumption of the test meal on the mRNA expression of membrane receptors in macrophages is shown in Fig. 4. The relative abundance of $L D L R$ mRNA transcripts exhibited a reduction of nearly $50 \%$ after the incubation of cells with TRL. The strength of the inhibition changed according to the postprandial time point, being significantly stronger with particles isolated at $2 \mathrm{~h}$ than with those isolated at $4 \mathrm{~h}$. The mRNA levels of $L R P$ were not affected after the incubation of cells with TRL, although a tendency towards inhibition of the expression was observed after the incubation of cells with TRL isolated at $2 \mathrm{~h}$. In contrast to those of $L D L R$ and $L R P$, the mRNA levels of $V L D L R$ were elevated by TRL treatment, but there were no significant differences between the effects exerted by TRL isolated at different postprandial time points.

The incubation of macrophages with postprandial TRL had similar effects on scavenger, non-apo E-dependent receptors as well as on the mRNA expression of each of the genes studied, as the abundance of transcripts was increased at all time points, with the exception of a slight inhibition of SRA2 expression in cells incubated with TRL isolated at $2 \mathrm{~h}$ postprandially. The lowest mRNA expression of these receptors was observed when cells were incubated with TRL isolated at $2 \mathrm{~h}$ after the consumption of the test meal, and it was significantly increased above this level when cells were incubated with TRL isolated at $4 \mathrm{~h}$, except in the case of VLDLR. A similar pattern was observed in the mRNA expression of $C D 36$, with a significantly higher expression being observed with particles isolated at $4 \mathrm{~h}$ than with particles isolated at $2 \mathrm{~h}$. No significant differences were observed in the abundance of transcripts when cells were incubated with particles isolated at 4 and $6 \mathrm{~h}$ when compared with control cells. The increase in mRNA expression in cells after treatment with TRL isolated at $6 \mathrm{~h}$ when compared with that in cells after treatment with TRL isolated at $2 \mathrm{~h}$ postprandially was significant for only SRB1.

\section{Discussion}

TRL are considered to be atherogenic particles, as they can be taken up by macrophages, leading to the formation of foam cells ${ }^{(13)}$. However, there is evidence indicating that not all
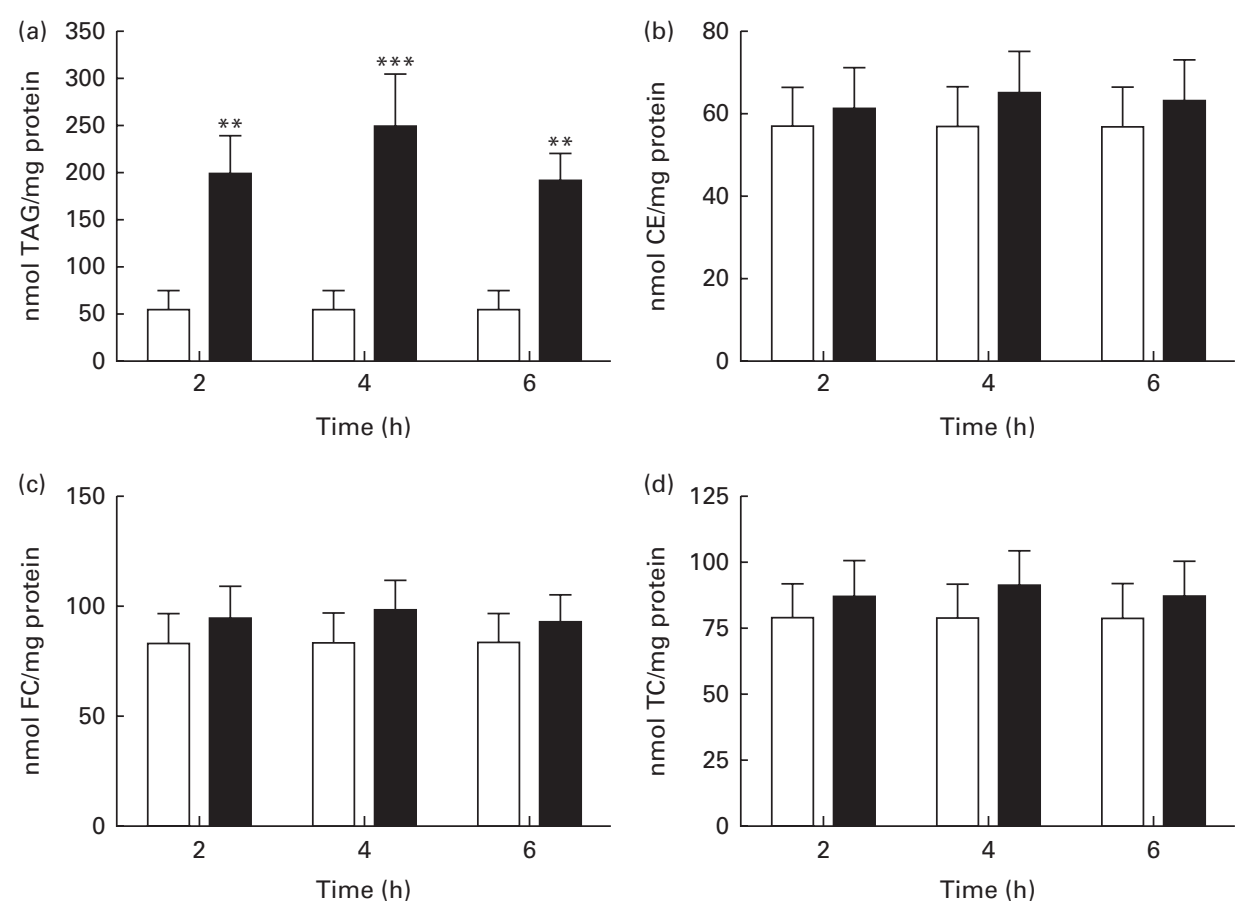

Fig. 3. Intracellular lipid accumulation in macrophages incubated for $24 \mathrm{~h}$ in the absence (control, $\square$ ) or presence of TAG-rich lipoproteins (TRL, $15 \mu \mathrm{g}$ total cholesterol/ml) isolated at 2, 4 and $6 \mathrm{~h}$ after the consumption of the test meal ( $\square$ ). (a) TAG, (b) cholesteryl esters (CE), (c) free cholesterol (FC) and (d) total cholesterol (TC). Values are means from nine separate experiments each using TRL obtained from different subjects, with their standard errors represented by vertical bars. Mean value was significantly different from that of control cells: ${ }^{\star \star} P<0 \cdot 01 ;{ }^{* \star *} P<0.001$. 


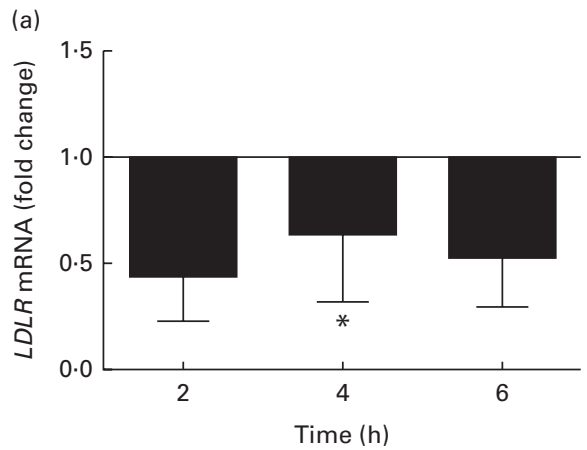

(c)
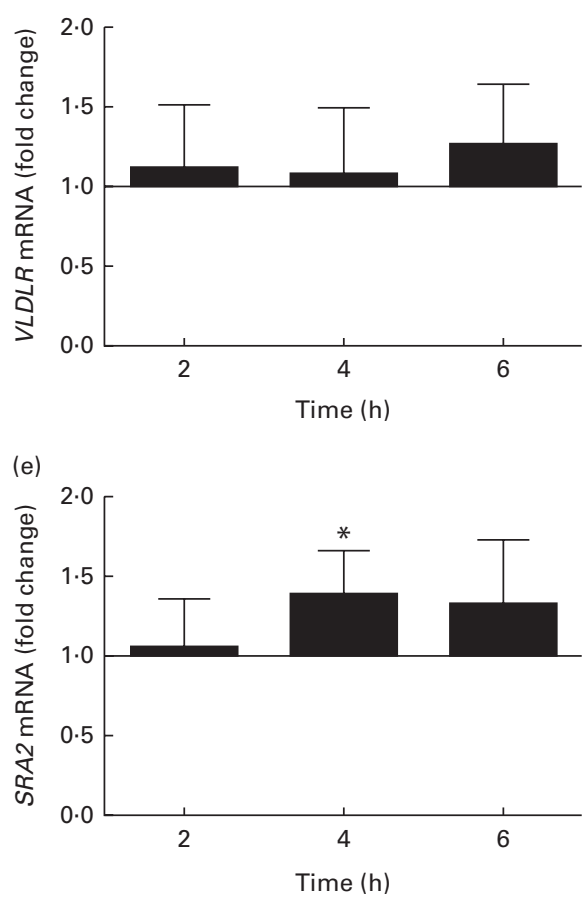

(b)

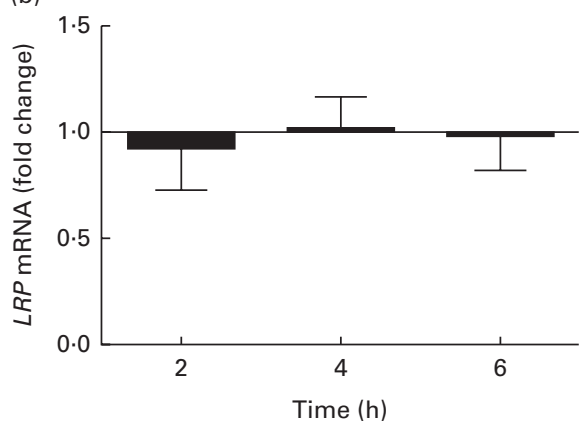

(d)

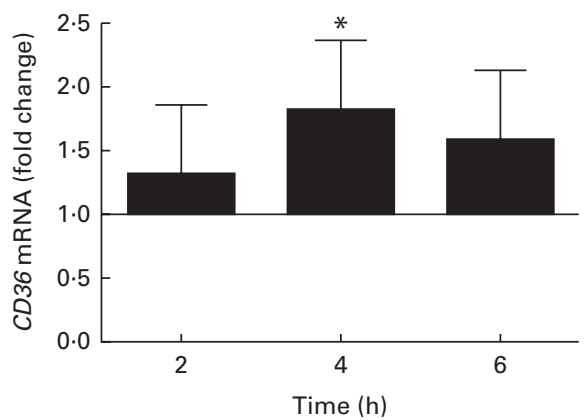

(f)

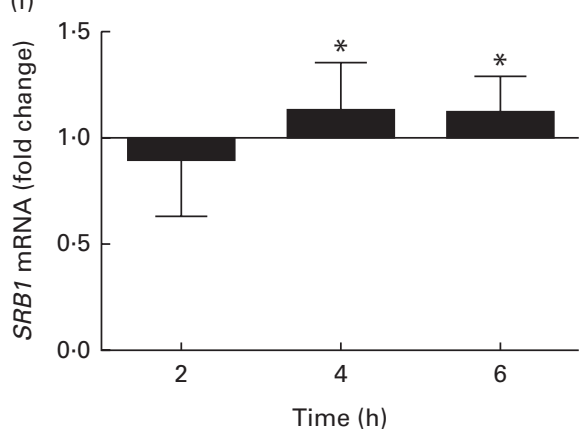

Fig. 4. Fold change in the mRNA expression of membrane receptors in macrophages incubated with (when compared with without) TAG-rich lipoproteins (TRL, $15 \mu \mathrm{g}$ total cholesterol/ml) isolated at 2,4 and $6 \mathrm{~h}$ after the consumption of the test meal. (a) LDL receptor (LDLR), (b) LDLR-related protein (LRP), (c) VLDL receptor (VLDLR), (d) scavenger receptor CD36 (CD36), (e) scavenger receptor class A type 2 (SRA2) and (f) scavenger receptor class $\mathrm{B}$ type 1 (SRB1). Values are means from nine separate experiments each using TRL obtained from different subjects, with their standard errors represented by vertical bars. ${ }^{\star}$ Mean value was significantly different from that of cells incubated with $T R L$ isolated at $2 \mathrm{~h}(P<0.05)$.

TRL are equally taken up by macrophages and that the particle size and composition of TRL may have a significant influence on the process of uptake and lipid accumulation ${ }^{(15)}$. In the present study, we investigated the influence of postprandial phase time on the composition of TRL and their receptorrelated uptake by macrophages.

The highest concentration of TAG in TRL was observed at $2 \mathrm{~h}$ after the consumption of the test meal, which declined at later time points (Table 2). TRL exhibited a progressive decrease in TAG concentrations throughout the postprandial period, but were proportionally enriched with phospholipids and CE. There was a change in the concentrations of apoB100 and apoB48 in TRL, although in this case the lowest concentrations were observed at $4 \mathrm{~h}$ postprandially. Estimation of the particle size of TRL from the TAG:apoB100 and TAG:apoB48 ratios indicated that there was a progressive decrease in particle size with time after the consumption of the test meal, as ratios were highest at $2 \mathrm{~h}$ and lowest at $6 \mathrm{~h}$. We have previously reported that TRL particles differing in size and composition can modulate the clearance of TRL postprandially, and this may affect the incorporation of TAG into the tissues ${ }^{(16-26)}$. Palmer et al. ${ }^{(19)}$ carried out a study to investigate the effect of particle size on the accumulation of TAG in THP-1 macrophages. They found a preferential accumulation of TAG in macrophages in response to incubation with large VLDL (Svedberg flotation rate (Sf) 60-400), i.e. intermediate-sized TRL particles, compared with small VLDL (Sf 20-60) or large-sized CM (Sf > 400). In agreement with this, the present results show that the highest uptake of TAG occurred when cells were incubated with TRL isolated at $4 \mathrm{~h}$ after the fat challenge, which was also the time point at which the estimated particle size was intermediate between that of particles isolated at 2 and $6 \mathrm{~h}$ (Fig. 3(a)). The use of the TAG:apoB ratio as an estimate of particle size is a limitation of the present 
study, but this ratio, as well as the cholesterol:apoB ratio, has been used for this purpose previously and proved to be reliable and convenient ${ }^{(16,20,27)}$. The fatty acid composition of dietary fat has been shown to modify the particle size of postprandial TRL in earlier studies. In this regard, Mekki et $a l .{ }^{(28)}$ showed that the intake of butter led to smaller circulating CM compared with the intake of olive or sunflower oils. However, it is unlikely that the changes observed in total TAG content and estimated particle size in the present study were related to modifications in the fatty acid TAG molecular species composition of postprandial TRL. In a recent study, we observed no significant changes in fatty acid or TAG molecular species composition related to the postprandial time point after the consumption of the same meal containing refined olive oil ${ }^{(20)}$. Vors et al. ${ }^{(29)}$ reported that in obese individuals, but not in normal-weight subjects, CM were larger when fat was administered as an emulsion than when consumed as a spread on bread. Although the metabolic consequences need to be investigated further, these results are of importance, as it has been proposed that milk derivatives should be used to standardise protocols for postprandial tests ${ }^{(30)}$.

The incubation of macrophages with postprandial TRL caused a highly significant increase in intracellular TAG concentrations, but did not have any effect on the cellular accumulation of FC and $\mathrm{CE}$. This result, together with the visualisation of the lipid content with Oil Red O staining, suggests that postprandial TRL induce the formation of foam cells in THP-1 cell populations mainly by TAG, rather than cholesterol, accumulation. Although there is a great deal of evidence from studies carried out both in vivo and with THP-1 macrophages to indicate that foam cell formation induced by native or modified LDL is caused by the accumulation of $\mathrm{CE}^{(31)}$, our findings are consistent with those of extensive previous work showing that $\mathrm{CM}$ remnants cause excessive TAG accumulation in human monocyte-derived macrophages as well as in the mouse macrophage cell line J774 and THP-1 macrophages ${ }^{(6,14,17,32,33)}$.

In macrophages, TAG are internalised not only via the direct uptake of fatty acids after lipoprotein lipase hydrolysis and subsequent re-esterification, but also by the uptake of whole particles by receptor-mediated pathways ${ }^{(19)}$; however, the exact mechanisms involved have not been defined completely. Current evidence suggests that CM remnants are mainly taken up via apoE-dependent pathways, mediated by LDLR and LRP1. In the present study, we observed that the incubation of macrophages with human TRL, isolated at different postprandial time points, induced a decrease in the mRNA levels of $L D L R$ in all cases (Fig. 4(a)). These findings are in agreement with those of previous work demonstrating a decreased mRNA expression of $L D L R$ after the incubation of THP-1 macrophages with CM remnants ${ }^{(14,34)}$. It is known that the expression of this receptor is inhibited by the intracellular accumulation of cholesterol due to lipoprotein uptake ${ }^{(34,35)}$. However, the results of the present study indicate that the reduction of $L D L R$ mRNA expression might also be caused by excessive TAG accumulation, as an increase in intracellular cholesterol concentrations was not observed.
It is clear from the extensive studies carried out over the past few years that receptors other than LDLR are involved in the uptake of TRL by macrophages ${ }^{(14,36)}$. Bejta et al. ${ }^{(14)}$ showed that LRP has a major role in the uptake of CM remnants by THP-1 macrophages. Others have also demonstrated that a decrease in the uptake of CM remnants by macrophages occurs when LRP is blocked by inhibitors ${ }^{(37)}$, although Mamo et al. ${ }^{(11)}$ did not find any evidence implicating LRP in this process. Palmer et $a l^{(19)}$ reported that VLDL and $\mathrm{CM}$ exert different effects on the expression of this receptor, which could be related to their particle size, but we were unable to find any significant effects of TRL isolated at different postprandial time points (Fig. 4(b)). VLDLR is another member of the LDLR superfamily that can bind to TRL remnants ${ }^{(38,39)}$ and may be involved in the formation of foam cells ${ }^{(40)}$. A modest up-regulation in the expression of this receptor was observed in the present study (Fig. 4(c)). However, no influence of the postprandial phase time was observed.

The expression of scavenger receptors (CD36, SRB1 and $S R A 2)$ is a characteristic feature of macrophages, and there is evidence suggesting that some of them have relevant roles in the uptake of TRL by different cells, including primary macrophages and THP-1 monocyte/macrophages ${ }^{(10,14,15)}$. Adenovirus-mediated overexpression of hepatic SRB1 can reduce serum VLDL- and CM-associated TAG concentrations ${ }^{(41)}$. Immunoblocking of $\mathrm{CD} 36$, and probably $\mathrm{SRB} 1^{(9)}$, has been shown to lower the incorporation of CM remnants into macrophages by $35-40 \%{ }^{(14)}$, leading to reduced CE, but not TAG, accumulation in cells, probably because the uptake of this lipid class is mainly mediated by lipoprotein lipase ${ }^{(9)}$. SRA2 plays a role in the formation of foam cells induced by $\mathrm{LDL}^{(42)}$, but little evidence is available on the part it may play in the uptake of TRL by macrophages. In the present study, the gene expression of these receptors was increased after the incubation of cells with all TRL particles, but to different extents, depending on the postprandial time point (Fig. 4(d)-(f)). The expression was low (SRA2 and CD36) or even inhibited (SRB1) when cells were incubated with particles isolated at $2 \mathrm{~h}$, while it was high when cells were incubated with particles isolated at $4 \mathrm{~h}$ in all cases. It is worth noting that the time-related effects of TRL on the expression of scavenger receptors were associated with the intracellular accumulation of TAG in macrophages. Indeed, the highest expression of these receptors occurred at $4 \mathrm{~h}$ postprandially, the time point at which TAG accumulation in cells was highest, suggesting that this receptor pathway may be actively contributing to the accumulation of TAG and the formation of foam cells.

In summary, the size and lipid composition of TRL were affected by the postprandial time point at which they were collected. TRL isolated at all time points studied caused considerable intracellular TAG accumulation in THP-1 macrophages, but the greatest increase was observed with particles of intermediate size, isolated at $4 \mathrm{~h}$ after the consumption of the test meal. For addition into the cell culture, TRL were normalised by cholesterol concentrations ( $15 \mu \mathrm{g}$ cholesterol $/ \mathrm{ml})$; thus, for each postprandial time point, a similar number 
of particles were added to the cell culture. It is known that receptor-mediated pathways play a role in the uptake of TRL by macrophages. Among those examined in the present study, the apoE-dependent receptors were expressed differentially in cells after treatment with postprandial TRL, with the expression of $L D L R$ being down-regulated and no effect being observed on that of $L R P$. In contrast, the expression of the apoB100-dependent $V L D L R$ was slightly up-regulated. A common feature of these receptors, however, was the absence of any sensitivity to the time point at which TRL were isolated. Conversely, scavenger receptors were more sensitive to the postprandial time point, with a higher mRNA expression being observed after the incubation of cells with the intermediate-sized TRL isolated at $4 \mathrm{~h}$, which also had the strongest effect on intracellular TAG concentrations. The results of the present study thus suggest that the atherogenicity of postprandial TRL varies with the time they are in the circulation, with those isolated at $4 \mathrm{~h}$ after the consumption of the meal being potentially most atherogenic, as they promote the formation of foam cells by increasing the accumulation of TAG in cells, possibly because of the up-regulation of the expression of scavenger receptors and, to a lesser extent, that of $V L D L R$.

\section{Acknowledgements}

The present study was supported by funds from the Spanish Ministry of Economy and Competitiveness (AGL2011-23810).

The authors' contributions are as follows: R. C.-M. and M. A. performed the experiments; E. M. recruited the subjects and performed the biochemical analyses; K. M. B., J. S. P. designed the study; L. S. and J. S. P. analysed the results; K. M. B., L. S. and J. S. P. wrote the article.

None of the authors has any conflicts of interest to declare.

\section{References}

1. Karpe F \& Hultin M (1995) Endogenous triglyceride-rich lipoproteins accumulate in rat plasma when competing with a chylomicron-like triglyceride emulsion for a common lipolytic pathway. J Lipid Res 36, 1557-1566.

2. Karpe F, Humphreys SM, Samra JS, et al. (1997) Clearance of lipoprotein remnant particles in adipose tissue and muscle in humans. J Lipid Res 38, 2335-2343.

3. Ginsberg HN (2002) New perspectives on atherogenesis: role of abnormal triglyceride-rich lipoprotein metabolism. Circulation 106, 2137-2142.

4. Patsch JR, Miesenböck G, Hopferwieser T, et al. (1992) Relation of triglyceride metabolism and coronary artery disease. Studies in the postprandial state. Arterioscler Thromb 12, 1336-1345.

5. Ginsberg HN \& Illingworth DR (2001) Postprandial dyslipidemia: an atherogenic disorder common in patients with diabetes mellitus. Am J Cardiol 88, 9H-15H.

6. Batt KV, Avella M, Moore EH, et al. (2004) Differential effects of low density lipoprotein and chylomicron remnants on lipid accumulation in human macrophages. Exp Biol Med 229, 528-537.

7. Moore EH, Napolitano M, Avella M, et al. (2004) Protection of chylomicron remnants from oxidation by incorporation of probucol into the particles enhances their uptake by human macrophages and increases lipid accumulation in the cells. Eur J Biochem 271, 2417-2427.

8. Moore EH, Bejta F, Avella M, et al. (2005) Efflux of lipid from macrophages after induction of lipid accumulation by chylomicron remnants. Biochim Biophys Acta 1735, 20-29.

9. Napolitano M \& Bravo E (2006) Evidence of dual pathways for lipid uptake during chylomicron remnant-like particle processing by human macrophages. J Vasc Res 43, 355-366.

10. Yu KC \& Cooper AD (2001) Postprandial lipoproteins and atherosclerosis. Front Biosci 6, D332-D354.

11. Mamo JC, Elsegood CL, Gennat HC, et al. (1996) Degradation of chylomicron remnants by macrophages occurs via phagocytosis. Biochemistry 35, 10210-10214.

12. Goulter AB, Avella MA, Elliott J, et al. (2002) Chylomicron remnant-like particles inhibit receptor-mediated endothelium-dependent vasorelaxation in porcine coronary arteries. Clin Sci (Lond) 103, 450-460.

13. Yu KC \& Mamo JC (2000) Chylomicron remnant-induced foam cell formation and cytotoxicity: a possible mechanism of cell death in atherosclerosis. Clin Sci (Lond) 98, 183-192.

14. Bejta F, Moore EH, Avella M, et al. (2007) Oxidation of chylomicron remnant-like particles inhibits their uptake by THP-1 macrophages by apolipoprotein E-dependent processes. Biochim Biophys Acta 1771, 901-910.

15. Botham KM \& Wheeler-Jones CP (2013) Postprandial lipoproteins and the molecular regulation of vascular homeostasis. Prog Lipid Res 52, 446-464.

16. Cabello-Moruno R, Perona JS, Osada J, et al. (2007) Modifications in postprandial triglyceride-rich lipoprotein composition and size after the intake of pomace olive oil. J Am Coll Nutr 26, 24-31.

17. De Pascale C, Avella M, Perona JS, et al. (2006) Fatty acid composition of chylomicron remnant-like particles influences their uptake and induction of lipid accumulation in macrophages. FEBS J 273, 5632-5640.

18. Karpe F (1999) Postprandial lipoprotein metabolism and atherosclerosis. J Intern Med 246, 341-355.

19. Palmer AM, Nova E, Anil E, et al. (2005) Differential uptake of subfractions of triglyceride-rich lipoproteins by THP-1 macrophages. Atherosclerosis 180, 233-244.

20. Cabello-Moruno R, Martinez-Force E, Montero E, et al. (2014) Minor components of olive oil facilitate the triglyceride clearance from postprandial lipoproteins in a polarity-dependent manner in healthy men. Nutr Res 34 , $40-47$.

21. Folch J, Lees M \& Sloane-Stanley GH (1957) A simple method for the isolation and purification of total lipides from animal tissues. J Biol Chem 226, 497-509.

22. Perona JS \& Ruiz-Gutierrez V (2004) Quantification of major lipid classes in human triacylglycerol-rich lipoproteins by high-performance liquid chromatography with evaporative light-scattering detection. J Sep Sci 27, 653-659.

23. Laemmli UK (1970) Cleavage of structural proteins during the assembly of the head of bacteriophage T4. Nature $\mathbf{2 2 7}$, $680-685$.

24. Karpe F \& Hamsten A (1994) Determination of apolipoproteins B-48 and B-100 in triglyceride rich lipoproteins by analytical SDS-PAGE. J Lipid Res 35, 1311-1317.

25. Pfaffl MW (2001) A new mathematical model for relative quantification in real-time RT-PCR. Nucleic Acids Res 29, e45.

26. Cabello-Moruno R, Perona JS \& Ruiz-Gutierrez V (2007) Influence of minor components of olive oils on the composition and size of TRLs and on macrophage receptors involved in foam cell formation. Biochem Soc Trans 35 , $470-471$. 
27. Tani S, Saito Y, Anazawa T, et al. (2011) Low-density lipoprotein cholesterol/apolipoprotein B ratio may be a useful index that differs in statin-treated patients with and without coronary artery disease: a case-control study. Int Heart J 52, $343-347$.

28. Mekki N, Charbonnier M, Borel P, et al. (2002) Butter differs from olive oil and sunflower oil in its effects on postprandial lipemia and triacylglycerol-rich lipoproteins after single mixed meals in healthy young men. $J$ Nutr 132, 3642-3649.

29. Vors C, Pineau G, Gabert L, et al. (2013) Modulating absorption and postprandial handling of dietary fatty acids by structuring fat in the meal: a randomized crossover clinical trial. Am J Clin Nutr 97, 23-36.

30. Lairon D, Lopez-Miranda J \& Williams C (2007) Methodology for studying postprandial lipid metabolism. Eur J Clin Nutr 61, 1145-1161.

31. Ghosh S, Zhao B, Bie J, et al. (2010) Macrophage cholesteryl ester mobilization and atherosclerosis. Vascul Pharmacol 52, $1-10$.

32. Napolitano M, Avella M, Botham KM, et al. (2003) Chylomicron remnant induction of lipid accumulation in J774 macrophages is associated with up-regulation of triacylglycerol synthesis which is not dependent on oxidation of the particles. Biochim Biophys Acta 163, 255-264.

33. Moore EH, Bejta F, Avella M, et al. (2005) Efflux of lipid from macrophages after induction of lipid accumulation by chylomicron remnants. Biochim Biophys Acta 1735, 20-29.

34. Batt KV, Patel L, Botham KM, et al. (2004) Chylomicron remnants and oxidised low density lipoprotein have differential effects on the expression of mRNA for genes involved in human macrophage foam cell formation. $J$ Mol Med (Berl) 82, 449-458.

35. Albertini R, Moratti R \& De Luca G (2002) Oxidation of low-density lipoprotein in atherosclerosis from basic biochemistry to clinical studies. Curr Mol Med 2, 579-592.

36. Kowala MC, Recce R, Beyer S, et al. (2000) Characterization of atherosclerosis in LDL receptor knockout mice: macrophage accumulation correlates with rapid and sustained expression of aortic MCP-1/JE. Atherosclerosis 149, 323-330.

37. Fujioka Y, Cooper AD \& Fong LG (1998) Multiple processes are involved in the uptake of chylomicron remnants by mouse peritoneal macrophages. J Lipid Res 39, 2339-2349.

38. Takahashi S, Suzuki J, Kohno M, et al. (1995) Enhancement of the binding of triglyceride-rich lipoproteins to the very low density lipoprotein receptor by apolipoprotein $\mathrm{E}$ and lipoprotein lipase. J Biol Chem 270, 15747-15754.

39. Niemeier A, Gàfvels M, Heeren J, et al. (1996) VLDL receptor mediates the uptake of human chylomicron remnants in vitro. J Lipid Res 37, 1733-1742.

40. Kosaka S, Takahashi S, Masamura K, et al. (2001) Evidence of macrophage foam cell formation by very low-density lipoprotein receptor: interferon- $\boldsymbol{\gamma}$ inhibition of very low-density lipoprotein receptor expression and foam cell formation in macrophages. Circulation 103, 1142-1147.

41. Out R, Hoekstra M, de Jager SC, et al. (2005) Adenovirusmediated hepatic overexpression of scavenger receptor class $\mathrm{B}$ type I accelerates chylomicron metabolism in C57BL/6J mice. J Lipid Res 46, 1172-1181.

42. Dhaliwal BS \& Steinbrecher UP (1999) Scavenger receptors and oxidized low density lipoproteins. Clin Chim Acta 286, 191-205. 